\title{
The features of the nitric oxide system in the left ventricle myocardium in the rats with experimental intermittent hypoxia of different duration
}

\author{
Yu. M. Kolesnyk ${ }^{A, F}$, M. I. Isachenko*B,C,D, O. V. Melnikova ${ }^{\mathrm{E}}$
}

Zaporizhzhia State Medical University, Ukraine

A - research concept and design; B - collection and/or assembly of data; C - data analysis and interpretation; D - writing the article; $\mathrm{E}$ - critical revision of the article; $\mathrm{F}$ - final approval of the article

Key words: nitric oxide synthase, NOS isoforms, left ventricle, heart, intermittent hypoxia, rats, Wistar.

Pathologia 2019; 16 (3), 308-314 DOl: 10.14739/2310-1237. 2019.3.188783

*E-mail: fedotova@zsmu.pp.ua
The aim was to determine the features of the NO system status in the left ventricular myocardium in the rats with intermittent hypoxic hypobaric hypoxia during 15 and 60 days.

Material and methods. The study was conducted on the 30 Wistar male rats, which were divided into 3 experimental groups: the $1^{\text {st }}$ - control, the $2^{\text {nd }}$ - rats exposed to intermittent hypoxia during 15 days and the $3^{\text {rd }}$ group - the rats exposed to intermittent hypoxia during 60 days. Blood pressure was measured in all the rats. The objects and methods of the study were blood plasma (nitrotyrosine detection with immunoassay) and the myocardium of the left ventricle (concentration of nitrites by Griess nitrite test and content of immunoreactive material to the nitric oxide synthase isoforms by immunofluorescence method). mRNA expression of NOS isoforms was determined by PCR-RT method in the myocardium.

Results. In the rats with 15-day hypoxia there was an increase in systolic pressure compared to control, and in 60-day hypoxia, there was also an increase in diastolic pressure although this changes were within the normotensive range. mRNA to all the myocardial NOS isoforms was characterized by an increase in both hypoxia groups.

At the same time, the indices of the immunoreactive material content to the NOS isoforms were dependent on the hypoxia term. The concentration of the nitrotyrosine increased in both hypoxic groups, but in the long term it occurred along with a decrease in the level of nitrite, which indicates the possibility of nitro-oxidative stress.

Conclusions. The 15-day intermittent hypoxia changes the myocardial NO system: an increase in the expression of all 3 isoforms, an increase in the nitrite and the nitrotyrosine content. iNOS becomes the predominant form of the enzyme in the myocardium with the increasing its mRNA. In 60-day hypoxia, the profile of the NOS enzyme is characterized by increased expression of the constitutive isoforms and decreased inducible NOS expression that was accompanied with significant increase in mRNA of all three forms. The level of terminal metabolites of NO was characterized by a decrease in the nitrite while the content of the nitrotyrosine increased.
Ключові слова: синтаза оксиАу азоту, ізоформи синтази оксиАу азоту, лівий шлуночок серця, переривчаста гіпоксія, щури мінії Wistar.

Патологія. - 2019. -

T. 16, № 3(47). -

C. 308-314

\section{Особливості системи оксиду азоту в міокарді лівого шлуночка щурів з експериментальною переривчастою гіпоксією різної тривалості}

\section{Ю. М. Колесник, М. І. Ісаченко, О. В. Мельнікова}

Мета роботи - встановити особливості стану системи NO в міокарді лівого шлуночка щурів при переривчастій гіпоксичній гіпобаричній гіпоксії тривалістю 15 і 60 днів.

Матеріали та методи. Дослідження здійснили на 30 щурах-самцях лінії Wistar, яких поділили на 3 експериментальні групи: 1 - контрольна, 2 - щури, які зазнавали впливу переривчастої гіпоксії протягом 15 днів, 3 група - щури 3 гіпоксією протягом 60 днів. Усім щурам вимірювали артеріальний тиск. Об'єкти дослідження - плазма крові, в якій імуноферментним методом визначали концентрацію нітротирозину, та міокард лівого шлуночка, в якому біохімічним методом Грісса досліджували концентрацію нітритів, імунофрлуоресцентним методом визначали вміст імунореактивного матеріалу до ізоформ синтази оксиду азоту. Також у міокарді методом ПЛР-РЧ визначали експресію мРНК до ізоформ NOS.

Результати. Хоча показники АТ у щурів із гіпоксією перебувають у нормотензивних межах, у групах із гіпоксією спостерігали збільшення систолічного тиску порівняно з контролем, а при 60-денній гіпоксії - збільшення і діастолічного тиску. мРНК до всіх ізоформ у міокарді характеризувалась збільшенням в обох групах із гіпоксією.

Показники вмісту імунореактивного матеріалу до ізоформ NOS змінювалися не так однозначно й мали залежність від терміну гіпоксії. Концентрація нітротирозину збільшилась в обох гіпоксичних групах, але при тривалій гіпоксії це відбулося на тлі зменшення рівня нітритів, що дає змогу припустити розвиток нітрозооксидативного стресу.

Висновки. 15-денна переривчаста гіпоксія призводить до зміни міокардіального ізоформного профрілю NOS, збільшення показників експресії всіх трьох ізоформ, підвищення вмісту нітритів і нітротирозину. Переважною формою ферменту в міокарді стає iNOS на тлі збільшення ії мPHК. При 60-денній гіпоксії профіль ферменту NOS характеризується збільшенням експресії конститутивних ізоформ і зниженням індуцибельної ізоформи на тлі істотного підвищення мPHК усіх трьох форм. Рівень кінцевих метаболітів NO характеризується зниженням нітритів, але збільшенням вмісту нітротирозину. 


\section{Особенности системы оксида азота в миокарде левого желудочка крыс с экспериментальной прерывистой гипоксией различной продолжительности}

\section{Ю. М. Колесник, М. И. Исаченко, О. В. Мельникова}

Цель работы - установить особенности состояния системы NO в миокарде левого желудочка крыс при прерывистой гипоксической гипобарической гипоксии продолжительностью 15 и 60 дней.

Материалы и методы. Исследование проведено на 30 крысах-самцах линии Wistar, которых поделили на 3 экспериментальные группы: первая - контрольная, 2 - крысы, которые подвергались прерывистой гипоксии в течение 15 дней, 3 группа - крысы с гипоксией в течение 60 дней. Всем крысам измеряли артериальное давление. Объекты исследования - плазма крови, в которой иммуноферментным методом определяли концентрацию нитротирозина, и миокард левого желудочка, в котором биохимическим методом Грисса исследовали концентрацию нитритов, иммунофлуоресцентным методом определяли содержание иммунореактивного материала к изоформам синтазы оксида азота. Также в миокарде методом ПЦР-РЧ определяли экспрессию мРНК к изоформам NOS.

Результаты. Хотя показатели АД у крыс с гипоксией находятся в нормотензивных пределах, в группах с гипоксией наблюдали увеличение систолического давления по сравнению с контролем, а при 60-дневной гипоксии - увеличение и диастолического. мРНК ко всем изоформам в миокарде характеризовалась увеличением в обеих группах с гипоксией. Показатели содержания иммунореактивного материала к изоформам NOS изменялись не так однозначно и имели взаимосвязь с продолжительностью гипоксии. Концентрация нитротирозина увеличилась в обеих гипоксических группах, но при длительной гипоксии это сопровождалось уменьшением уровня нитритов, что позволяет предположить развитие нитрозооксидативного стресса.

Выводы. 15-дневная прерывистая гипоксия приводит к изменению миокардиального изоформного профиля NOS, увеличению показателей экспрессии всех трех изоформ, повышению содержания нитритов и нитротирозина. Преобладающей формой фермента в миокарде становится iNOS на фоне увеличения ее мРНК. При 60-дневной гипоксии профиль фермента NOS характеризуется увеличением экспрессии конститутивных изоформ и снижением индуцибельной изоформы на фоне повышения мРНК всех трех форм. Уровень конечных метаболитов NO характеризуется снижением нитритов и увеличением содержания нитротирозина.

Nitric oxide (NO) system is a gasotransmitter system that is widely represented in all tissues of the body. Its main effector is the NO molecule, which is the universal regulator of cellular metabolism and intercellular relationships under physiological conditions. But the effect of NO depends on the concentration, the presence of substrates, metabolites of oxidative stress and antioxidants. With their excess, the amount of $\mathrm{NO}$ increases, and its signaling and physiological functions change to pathological, triggering processes that lead to apoptosis or cell necrosis. The purpose of changing the state of this system in response to physiological effects or stressors is to improve functioning and adapt to new conditions [1].

Hypoxia is one of the classic examples of physiological stress, but the extent of its manifestation depends on the duration, severity and origin. In this case, the organism and its regulatory systems will change their function in the context of the adaptive response. The cardiovascular system is not an exception to these changes. The heart adapts to this effect by remodeling myocardium, which is named physiological [2,3].

The issue of hypoxic effects on the state of the NO system of organism is very relevant today, including both experimental studies and clinical observations. It is necessary to emphasize the researches devoted to the effects on the heart muscle. Thus, in the works of E. B. Manukhina (2006) and A. Treuer (2014) it was proved that the NO system is an important component of adaptation to the conditions of intermittent hypoxia $[4,5]$. It has been established that it affects the state of the myocardial NO system in several ways: firstly, it generates substrate deficiency and, through limiting $\mathrm{O}_{2}$ influx, reduces NO production [4]; alters the isoform profile of NOS through activation of $\mathrm{Ca}^{2+} /$ calmodulin-dependent isoforms of NOS (eNOS and
nNOS), mainly endothelial (eNOS), which compensates for the reduction of $\mathrm{NO}$, increases its bioavailability and improves tissue vascularization [5]; secondly, it activates heat shock proteins, including HSP90, which not only stimulates constitutive isoforms but also prevents the formation of anion superoxide during NO synthesis [6] and stimulates hypoxia-induced factor $1 \alpha(\mathrm{HIF}-1 \alpha)$ and $1 \beta$ (HIF-1 $\beta$ ) acting as a transcriptional mediator. This protein is inactivated by an oxygen-dependent ubiquitin-proteasome system under normoxic conditions. HIF-1 1 a translocates to the nucleus and induces target genes that lead to the development of myocardial hypertrophy, increases angiogenesis, erythrocytosis, stimulates cell metabolism by activating pyruvate dehydrogenase- 1 and/or lactate dehydrogenase enzyme under hypoxic conditions [7].

Our previous studies of the NO system role in the pathologic myocardial remodeling caused by essential arterial hypertension in SHR rats have confirmed the assumption of the pathogenetic importance of this system as one of the possible conductors of cardiac muscle reconstruction [8]. However, the question of changes in the NO system under physiological effects, such as intermittent hypoxia, remains open. NO system triggers probably an entire cascade of adaptive responses in the conditions of oxygen deficiency modified by the mechanisms described above that is aimed to improvement of the myocardium function. But there is no complete information about the NO system status, the characteristics of the isoform profile of NOS and terminal metabolites in the myocardium at the hypoxic exposures of different duration.

\section{Aim}

Therefore, in order to understand the role of the nitric oxide system in myocardial remodeling caused by hypoxia of
Ключевые слова: синтаза оксиАа азота, изоформы синтазы оксила азота, левый желудочек сердца, гипоксия, крысы минии Wistar.

Патология. - 2019. -

T. 16, № 3(47). C. $308-314$ 
different duration, the aim of our study was to determine the features of the NO system status in the left ventricular myocardium in the rats with intermittent hypoxic hypobaric hypoxia during 15 and 60 days.

\section{Materials and methods}

The experiment was conducted on the 30 male Wistar rats, 6-7 months old which were divided into 3 experimental groups: the control group - intact rats (mean heart mass $-0.722 \pm 0.03 \mathrm{~g}$; specific density of the heart $1.724 \pm$ $\left.0.07 \mathrm{~g} / \mathrm{cm}^{3}\right)$, the second group - $-\mathrm{H} 15$ - the rats with intermittent hypoxia during 15 days (mean heart mass -0.851 $\pm 0.03 \mathrm{~g}$; specific density of the heart $1.817 \pm 0.07 \mathrm{~g} / \mathrm{cm}^{3}$ ), the third group - $\mathrm{IH} 60$ - the rats with intermittent hypoxia during 60 days (mean heart mass $-0.902 \pm 0.03 \mathrm{~g}$; specific density of the heart $2.102 \pm 0.26 \mathrm{~g} / \mathrm{cm}^{3}$ ).

Hypoxic training was performed in a ventilated pressure chamber with a volume of $1.0 \mathrm{~m}^{3}$ at an altitude of $6000 \mathrm{~m}\left(\mathrm{pO}_{2}=9.8 \%\right)$ using a model widely used in the research of the Department of Pathological Physiology of ZSMU [9]. Animals were housed in the pressure chamber daily from $10 \mathrm{am}$ to $4 \mathrm{pm}$. The training was conducted in the following mode: the $1^{\text {st }}$ day oxygen tension in the pressure chamber corresponded to the height of $1 \mathrm{~km}$, the $2^{\text {nd }}$ day $-2 \mathrm{~km}$, the $3^{\text {rd }}-3 \mathrm{~km}$, the $4^{\text {th }}-4 \mathrm{~km}$, on the $5^{\text {th }}-5 \mathrm{~km}$, on the $6^{\text {th }}$ and during the following days $-6 \mathrm{~km}$. Hypoxic training at a height of $6 \mathrm{~km}$ was performed for 10 days for 15-day hypoxia and 55 days for 60 -day. The "lift height" in the pressure chamber was registered by an altimeter.

The experimental part of the study was carried out exactly according to the National "Common Ethical Principles of Animal Experiments" (Ukraine, 2001), which are in accordance with the Directive 2010/63EU of the European Parliament and of the Council of September 22, 2010 on the protection of animals used for scientific purposes. The protocol of the study is agreed with the local ethics committee (from March 1, 2018). [10].

The experiment was conducted on the basis of the Training Medical Laboratory Center (TMLC) of the Zaporizhzhia State Medical University. All devices used for study are certificated and undergo annual metrological control (certificate of technical competence № 033/18, dated December 25, 2018, valid until December 25, 2023; Laboratory of Experimental Pathophysiology, License 2CK2 YMK2 T6PB SG5N SJLS4).

Systolic and diastolic blood pressure (BP) levels were measured in all the rats using a system of non-invasive arterial pressure measurement BP-2000 (Visitech Systems, USA).

The animals were euthanized via rapid decapitation after thiopental anesthesia ( $45 \mathrm{mg} / \mathrm{kg}$ body weight, intraperitoneally). The study objects in the experimental animals were blood plasma, in which the nitrotyrosine level was determined, and the left ventricle fragment, which was divided into two parts, one of which was homogenized using a Silent Crusher S homogenizer (Heidolph, Germany), the second fragment of the heart after standard histological preparation was fixed in paraplast blocks.

The blood plasma nitrotyrosine concentration in the rats was determined by immunoassay according to the instructions for the reagent set (Hycultbiotech, HK501 - Nitrotyrosine). The level of nitrites in homogenates of the first fragments of the left ventricular myocardium was determined by the biochemical Griess nitrite test on the Libra S 32 PC spectrophotometer [11].

The second fragment of the myocardium was sectioned into $5 \mu \mathrm{m}$-thick slices using a rotary microtome Microm-325 (MicromCorp, Germany). In these slices concentration of the immunoreactive material to NOS isoforms was determined with immunofluorescence method in accordance with the protocol of the immunohistochemical study [12].

To study nNOS and eNOS expression serial slices after procedure of deparaffinization and rehydration were incubated with primary polyclonal rabbit anti-nNOS and anti-eNOS antibodies, respectively, (1: 200; Santa Cruz Biotechnology, Inc., USA). After rinsing sections were incubated with the secondary FITC-conjugated rabbit anti-mouse antibodies (1:200; Santa Cruz Biotechnology, Inc.). To determine the iNOS expression, the slices of the myocardium were incubated with monoclonal FITC-conjugated mouse antibodies against iNOS (1: 200; Santa Cruz Biotechnology, Inc.).

The immunofluorescence study was performed separately in transverse and longitudinal fibers. The sections were examined with ultraviolet microscopy (AxioScope microscope, Carl Zeiss, Germany) in AxioVision $40 \mathrm{~V}$ 4.8.2.0 software program (License No. 3005339) with an excitation wavelength $390 \mathrm{~nm}$, using a filter $38 \mathrm{HE}$ with high emission (Carl Zeiss, Germany). Zones with statistically significant fluorescence were identified while analyzing the images in the interactive mode and then analyzed in Image J software (National Institutes of Health, USA). At least 100 fields of view from each series were subjected for study.

The study of NOS mRNA isoforms expression in the left ventricular myocardium homogenates was carried out using a real-time polymerase chain reaction (RT-PCR) in the Department of Molecular Genetic Researches of the TMLC of ZSMU [8]. For RT-PCR in real time with the gene specific primers CFX96 TM Real-Time PCR Detection Systems (Bio-Rad Laboratories Inc., USA) were used in accordance with the manufacturer's recommendations and Maxima SYBR Green/ROX qPCR Master Mix (2X) reagent kit (Thermo Fisher Scientific, Inc.).

All statistical computations were performed in the Microsoft Excel 2016 table processor (Microsoft Corp., USA). For all parameters, the arithmetic mean (M), its dispersion and mean error $(\mathrm{m})$ were calculated. To determine the significance of differences between the results of the research in the experimental and control groups of the rats, the Student's coefficient $(t)$ was calculated, after that the significance of the difference between the samples ( $p)$ and the confidence interval of the mean according to the Student distribution tables were determined. Valid values for $P_{S t}<0.05$ were considered statistically significant [13].

\section{Results}

Analysis of the BP in the experimental rats showed that the systolic and diastolic pressure was in the normotensive 
range, but in the $\mathrm{IH} 15$ rat group, the systolic pressure significantly increased by $8 \%$ in comparison with the control group.

Moreover, IH60 showed a significant increase of both systolic by $17.4 \%$ and diastolic pressure by $21.3 \%$ compared to the control values (Table 1). Increase of blood pressure occurred both with an increase in mean heart mass and specific heart density of the rats in the $\mathrm{IH} 15$ group by $17.9 \%$ and by $5.4 \%$, in rats with $\mathrm{IH} 60$ by $25.0 \%$ and $21.9 \%$, respectively, compared with controls.

The study of mRNA expression of all three NOS isoforms demonstrated that intermittent hypoxia, regardless of its duration, leads to increase of iNOS mRNA, whereas nNOS and eNOS mRNA increases only after prolonged training - IH60 (Fig. 1).

Analysis of the nNOS expression indices in $\mathrm{IH} 15$ group of the rats showed a significant decrease of the IRM content to nNOS in the transverse fibers by $20.6 \%$, while in the longitudinal ones the content of the IRM did not change compared to the control (Table 2). The nNOS mRNA content in the left ventricular myocardial homogenates did not change significantly (Fig. 1). IRM content of iNOS increased by $7.2 \%$ compared to control in transverse fibers, and significantly increased by $14.7 \%$ in longitudinal fibers (Table 2). At the same time, the content of iNOS mRNA in myocardial homogenates significantly increased by 2.9 times compared to the control (Fig. 1). The analysis of eNOS expression indices revealed a significant increase in the IRM content to eNOS by $6.6 \%$ in the myocardial transverse fibers, whereas there were no significant changes in the longitudinal fibers (Table 2). The expression of eNOS mRNA in this group did not change significantly.

In the IH60 group, the expression of IRM to nNOS showed more significant changes than in the $\mathrm{IH} 15$ group as compared to control. At the same time, the transverse fibers showed a significant increase in the content of IRM to nNOS by $25.4 \%$. In the longitudinal fibers, the nNOS content was significantly increased by $45.7 \%$ (Table 2), and the corresponding mRNA in myocardial homogenates was 2-fold increased compared to the control group (Fig. 1). In the study of the content of IRM to iNOS, both in transverse and longitudinal myocardial fibers, there was a significant decrease in the content by $26.1 \%$ and $33.3 \%$, respectively, compared to the control (Table 2). The content of iNOS mRNA after a prolonged hypoxia dur- ing 60 days increased 5.7 times significantly compared to the control (Fig. 1). In this group, compared to the control, there was a significant increase in the content of IRM to eNOS by $7.5 \%$ in the transverse fibers, but a decrease of $11.9 \%$ in the longitudinal fibers (Table 2). The mRNA content of this isoform demonstrated significant 4.1-fold increase compared to the control group (Fig. 1).

For better understanding of the myocardial nitric oxide system state during intermittent hypoxic exposure, it is necessary to investigate not only the isoform profile of the NOS enzyme, but also the terminal metabolites of NO: nitrite and nitrotyrosine. The nitrites concentration is considered by most scientists as the equivalent of NO formation, demonstrating the enzymatic activity of NOS and the physiological orientation of the effects of the nitric oxide system [14]. In our study, nitrites concentration in the $\mathrm{IH} 15$ group increased by $21 \%$ compared to controls, but in the $\mathrm{IH} 60$ group, this indicator decreased significantly by $21.8 \%$. At the same time, nitrotyrosine, which is synthesized from the NO derivative - peroxynitrite under conditions of excessive formation of reactive oxygen species, is an indicator of nitrosative-oxidative stress, so it is considered as a marker of NO-dependent damage in vivo [15]. The concentration of the nitrotyrosine in the $\mathrm{IH} 15$ group significantly increased by $40.8 \%$, in the $\mathrm{IH} 60$ rats group - by $80.6 \%$ compared to the control (Fig. 2).

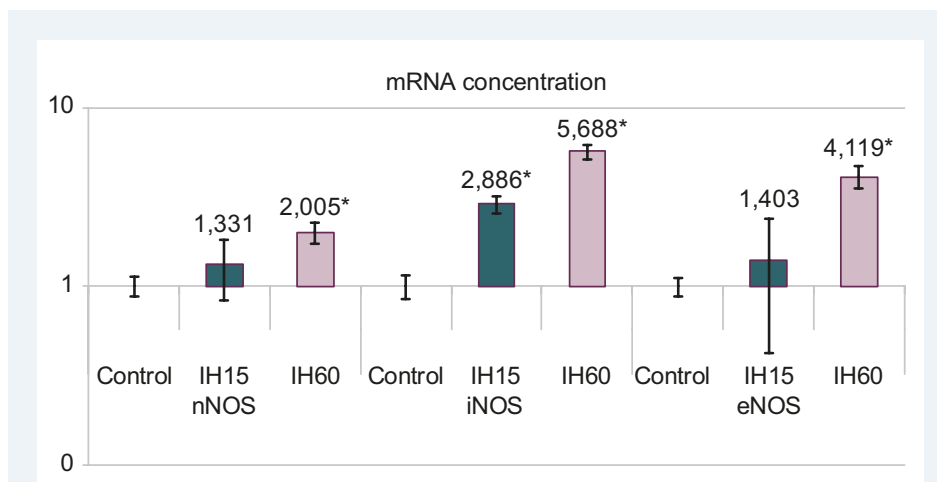

Fig. 1. mRNA expression of NOS isoforms in the left ventricular myocardium of experimental rats. The data are presented as $M \pm m$.

*: significance of the differences in comparison with the control group $P<0.05$

Table 1. Blood pressure in the rats of experimental groups

\begin{tabular}{l|l|l|l} 
BP, $\mathbf{m m H g}$ & Control & IH15 & IH60 \\
\hline Systolic & $115.05 \pm 1.76$ & $123.40 \pm 2.05^{\star}$ & $135.10 \pm 1.69^{*}$ \\
Diastolic & $68.10 \pm 1.23$ & $69.30 \pm 1.94^{\S}$ & $82.60 \pm 3.18^{*}$ \\
\hline
\end{tabular}

*: significance of the differences in comparison with the control group $\mathrm{P}<0.05$; §: significance of the differences in comparison with the IH60 group $\mathrm{P}<0.05$.

Table 2. The content of IRM of NOS isoforms ( $\mathrm{nNOS}$, iNOS and eNOS) in the left ventricular myocardium of the experimental rats, $\mathrm{M} \pm \mathrm{m}$

\begin{tabular}{|c|c|c|c|c|c|c|}
\hline & \multicolumn{2}{|l|}{ Control } & \multicolumn{2}{|l|}{ IH15 } & \multicolumn{2}{|l|}{$\mathrm{IH} 60$} \\
\hline & transv. fibers & longitud. fibers & transv. fibers & longitud. fibers & transv. fibers & longitud. fibers \\
\hline nNOS & $1198.0 \pm 19.7$ & $1236.0 \pm 29.6$ & $951.7 \pm 25.9^{*}$ & $1218.6 \pm 30.8$ & $1501.8 \pm 33.8^{\star} \S$ & $1800.8 \pm 26.4^{\star \S}$ \\
\hline iNOS & $1102.1 \pm 16.8$ & $1185.2 \pm 21.9$ & $1181.7 \pm 36.6^{*}$ & $1359.8 \pm 32.1^{*}$ & $814.6 \pm 27.9^{*} \S$ & $790.3 \pm 22.9^{*} \S$ \\
\hline eNOS & $1099.6 \pm 18.5$ & $1252.7 \pm 17.7$ & $1172.7 \pm 22.3^{*}$ & $1254.7 \pm 35.5$ & $1182.0 \pm 23.4^{*}$ & $1103.9 \pm 21.2^{\star \S}$ \\
\hline
\end{tabular}

*: significance of the differences in comparison with the control group $P<0.05$;

$\S$ : significance of the differences in comparison with the IH60 group $\mathrm{P}<0.05$. 
Nitrits concentration, uM/L

10

8

6

4

2

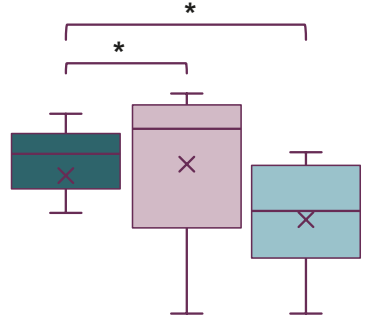

Intact $\square \mathrm{IH} 15 \square \mathrm{IH} 60$
Nitrotyrosine concentration, UM/L

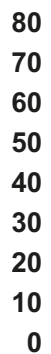

Fig. 2. Concentration of nitrites in left ventricular myocardium homogenates and nitrotyrosine in blood plasma of the experimental rat groups. The data are presented as median, the $1^{\text {st }}$ and the $3^{\text {rd }}$ quartiles, min and max.

*: significance of the differences $P<0.05$.

\section{Discussion}

An interesting result of our study was an increase in systolic pressure in $\mathrm{IH} 15$ rats and both systolic and diastolic in IH60 compared to the control group. Such increased $\mathrm{BP}$ is within the reference values and may be associated with an increase of stroke volume. It is possible that the increase in stroke volume is explained by myocardial hypertrophy, as it is evidenced by the gradual increase in mean heart mass and specific density of the rat's heart. Normally, the phenomenon of Euler-Liljestrand develops as the component of adaptation to hypoxic condition. The essence of the phenomenon is the decrease in the tone of the systemic circulation vessels, their vasodilation, which reduces the peripheral vascular resistance and compensates for the oxygen demand of organs and the heart, in particular. These processes are accompanied by an increase in the vascular reserve, which enhances myocardial capacity, improves blood supply and contractility in conditions of increased pumping function $[16,17]$. The $\mathrm{BP}$ of the rats with long-term hypoxia suggests a possible increase in total vascular resistance. Moreover, it evidences the presence of these systemic rearrangements that is based on structural and functional changes at the cellular level which is provided with the whole complex of gasotransmitter and mediator systems, the key element of which is the NO system.

The obtained data of the myocardium NO system of the rats with intermittent hypoxia prove numerous facts of other researchers who argue that the shortterm intermittent hypoxia leads to activation of urgent adaptation mechanisms, an important component of which they considered nitric oxide and NOS isoforms $[1,4,5]$. Zhang Y. (2017) considers that the features of compartmentalization, translocation, transcription, and post-translational modifications of constitutive NOS isoforms mediate the effects of $\mathrm{NO}$ in the myocardium during physiological and pathological stress [18]. Interestingly, their expression is regulated by negative feedback: if nNOS expression increases, eNOS expression decreases. Such interrelation is aimed to prevent NO overproduction under normal conditions and maintain its stable level under stress. In the case of "blocking" of one isoform the other isoform will compensate for the lack of NO due to its increased expression and activity [19]. In our case, the increase in the IRM content of nNOS and eNOS in $\mathrm{IH} 15$ rats along with an increase in their mRNA can be considered as confirmation of this hypothesis and considered as the one of the components of urgent adaptation to hypoxia in the myocardium. Such activation of the constitutive isoforms expression is likely to improve cardiomyocyte contractility, modulation of sympathetic and parasympathetic effects, control of cardiac rhythm and regulation of cell metabolism, by improving local vascularization and innervation.

Several years ago, the increase in iNOS expression in the myocardium in $\mathrm{IH} 15$ rats was explained by its injuring ability, but recent studies have proven the cardioprotective role of inducible NOS isoforms. So, according to D. J. Lefer, iNOS is the primary source of cardioprotective NO, which modulates coronary circulation, mitochondrial function, cellular respiration and reduces platelet aggregation [20]. In the condition of oxygen deficiency and insufficient activity of constitutive NOS isoforms, iNOS activation is believed to be a component of the adaptive response to hypoxia and maintenance of stable NO level. But iNOS excessive activity leads to the explosive formation of NO, which has a cytostatic effect, due to the excessive formation of the free radicals. An interesting finding was that the mRNA increase of this isoform was 2.9-fold with 15-day hypoxia compared to control. Such an increase in mRNA is likely to indicate myocardium significant need for iNOS with the stimulation of transcriptional mechanisms [21].

In our opinion, a $21 \%$ increase in nitrites level in $\mathrm{IH} 15$ rat myocardial homogenates is an important indicator of increased NO synthesis due to the high activity and expression of NOS. The same pattern was obtained by La Padula (2018) group, who proved the effect of intermittent hypoxia on the increase of terminal metabolites of NO level [22].

Another result of the study was the establishment of elevated nitrotyrosine level in myocardial homogenates after 15 days of hypoxic training. Today, the mechanism of nitrotyrosine formation and its role in pathological conditions is well defined, so the increase in its level 
together with the high expression of all 3 isoforms, especially iNOS, is associated with the switching of NOS from NO-production to ROS formation and the development of the nitrosative-oxidative stress. That is, 15-day hypoxic training contributes not only to the activation of adaptive abilities of the body, as it is defined in our work. Whereas, there are pathological changes, isoform imbalance in the NO system, which contributes for the development of oxidative stress at this stage.

Long-term 60-day hypoxic training also led to significant changes in the myocardial nitric oxide system, which is characterized by an increase in constitutive isoforms with a simultaneous decrease in iNOS and a significant increase in concentrations of stable NO metabolites, and these changes had significant difference compared to $\mathrm{IH} 15$ results. The study of the NOS isoform profile showed increased expression of nNOS in the both transverse and longitudinal fibers of the myocardium sections with a 2-fold increase in its mRNA compared to the control. Moreover, the nNOS content in transverse and longitudinal fibers increased by more than one third compared to $\mathrm{IH} 15$. This high expression of nNOS, according to other researchers, is associated with its proven cardioprotective role. Along with the synthesis of $\mathrm{NO}$ nNOS also forms $\mathrm{H}_{2} \mathrm{O}_{2}$ in the wall of large vessels forms, which improves vascularization and is a component of adaptation to hypoxia. At the same time, nNOS inhibits cardiac oxidases, decreases sources of oxidative stress, thus exhibiting antioxidant properties [23].

Expression of eNOS isoform in transverse fibers of $\mathrm{IH} 60$ rats increased compared to control. This occurred with a significant 4.1-fold raise in its mRNA, which indicates an increase in eNOS synthesis and content after prolonged hypoxic training is related to its cardioprotective properties [24]. According to many studies, this isoform is associated with the activation of vasodilation and collateral circulation that maintain the metabolism of cardiomyocytes and protects it from free radical damage. Hypoxia has been shown to increase $\mathrm{Ca}^{2+}$ influx through L-type $\mathrm{Ca}^{2+}$ channels, which activates eNOS and stabilizes HIF1 , thereby maintaining a feedback loop. All these reactions lead to the enhancement of NO synthesis and myocardial adaptation development $[25,26]$.

Analysis of iNOS expression indices after prolonged hypoxic training for 60 days showed a decrease in its content compared to the control, in contrast to its increased expression as in $\mathrm{IH} 15$. However, this was accompanied with significant 5.7-fold increase in iNOS mRNA compared to control and almost 2-fold increase compared to $\mathrm{IH} 15$. Such ambiguous results, in our opinion, indicate genome activation, the presence of the transcriptional block of iNOS expression and the accelerated destruction of the enzyme in the myocardium. Rus A. (2011) supposed that negative effects associated with the lack of protective NO in the myocardium are formed, which reduces the activity of antioxidant enzymes and the expression of the coding genes, accelerates lipid peroxidation, increases the formation of ROS [27]. The decrease in the concentration of nitrites along with increased levels of the nitrotyrosine is an indirect fact that confirmed this assumption. The data obtained indicate the reduction of $\mathrm{NO}$ formation by $\mathrm{NO}$ enzymatic pathway and demonstrate the switching of the
NO system to nitrosative-oxidative stress, which obtains a systemic character.

Thus, the results of our study revealed that hypoxic effects, regardless of their duration, activate the NO system in the myocardium by quantitative increase in content of NOS isoforms and terminal NO metabolites. Whereas, it should be noted that the nature of the NOS isoform profile and the type of the terminal metabolite NO depend on the duration of hypoxic exposure. Thus, in short-term training an increase in endothelial vasodilating factor NO due to excessive synthesis of iNOS, which activity, unlike constitutive isoforms, remains high, regardless of oxygen concentration and intracellular $\mathrm{Ca}^{2+}$ level to compensate blood flow in the myocardium. Whereas, under the action of long-term hypoxia, the mechanisms of adaptation involved in the classical scheme of a "systemic structural trace" formation are activated: maintenance of metabolic processes, restoration of blood supply, genome activation, and stimulation of mRNA expression of all three NOS isoforms. But the large amount of NO which is formed with excess of peroxynitrite and nitrotyrosine in hypoxic condition that damages the tissue components of the myocardium trigger a cascade of reactions which yields in nitrosative-oxidative stress. The last one, in turn, has additional injuring effect on the myocardium, causing its pathological remodeling instead of physiological one.

\section{Conclusions}

1. 15-day intermittent hypoxia leads to a change in the myocardial NOS isoform profile, an increase in the expression of IRM to all 3 isoforms, an increase in the nitrite and nitrotyrosine content. iNOS becomes the predominant form of the enzyme in the myocardium that is proved with increasing its $\mathrm{mRNA}$.

2. 60-day hypoxia, compared with 15-day hypoxia, results in opposite changes in the isoform composition of myocardial NOS. The profile of the NOS enzyme is characterized by increased expression of constitutive isoforms and decreased inducible with significant increase in mRNA of all three isoforms. The level of terminal metabolites of $\mathrm{NO}$ is characterized by a decrease in the nitrite content while the nitrotyrosine content increased.

Conflicts of interest: authors have no conflict of interest to declare. Конфлікт інтересів: віАсутній.

Надійшла до редакції / Received: 05.09.2019

Після Аоопрацювання / Revised: 23.10.2019

Прийнято Ао Аруку / Accepted: 11.11.2019

Information about authors:

Kolesnyk Yu. M., MD, PhD, DSc, Professor, Rector of Zaporizhzhia

State Medical University, Honorary Scientist and Engineering

Worker of Ukraine.

ORCID ID: 0000-0002-1556-5085

Isachenko M. I., MD, Postgraduate Student of the Department

of Pathophysiology, Zaporizhzhia State Medical University,

Ukraine.

ORCID ID: 0000-0002-3026-1012 
Melnikova 0. V., MD, PhD, Associate Professor of the Department of Pathophysiology, Zaporizhzhia State Medical University, Ukraine.

ORCID ID: 0000-0002-6807-8440

\section{Відомості про авторів:}

Колесник Ю. М., А-р меА. наук, професор, ректор Запорізького Аержавного медичного університету, заслужений Аіяч науки і техніки України.

Ісаченко М. І., очний аспірант каф. патологічної фізіології, Запорізький Аержавний медичний університет, Україна. Мельнікова О. В., канА. меА. наук, Аоцент каф. патологічної фізіології, Запорізький Аержавний медичний університет, Україна.

\section{Сведения об авторах:}

Колесник Ю. М., А-р меА. наук, профессор, ректор Запорожского государственного меАицинского университета, заслуженный деятель науки и техники Украины.

Исаченко М. И., очный аспирант каф. патологической физиологии, Запорожский государственный медицинский университет, Украина.

Мельникова О. В., канА. меА. наук, Аоцент каф. патологической физиологии, Запорожский государственный медицинский университет, Украина.

\section{References}

[1] De Haas, S., Ghossein-Doha, C., Geerts, L., van Kuijk, S. M. J., van Drongelen, J., \& Spaanderman, M. E. A. (2017). Cardiac remodeling in normotensive pregnancy and in pregnancy complicated by hypertension: Systematic review and meta-analysis. Ultrasound in Obstetrics and Gynecology, 50(6), 683-696. https://doi.org/10.1002/uog.17410

[2] Yalçin, F., Kucukler, N., Cingolani, O., Mbiyangandu, B., Sorensen, L., Pinherio, A., .. A Abraham, T. P. (2019). Evolution of ventricular hypertrophy and myocardial mechanics in physiological and pathological hypertrophy. Journal of Applied Physiology, 126(2), 354-362. https:/ doi.org/10.1152/japplphysiol.00199.2016

[3] Haque, Z. K., \& Wang, D. (2017). How cardiomyocytes sense pathophysiological stresses for cardiac remodeling. Cellular and Molecular Life Sciences, 74(6), 983-1000. https://doi.org/10.1007/s00018-016-2373-0

[4] Manukhina, E. B., Downey, H. F., \& Mallet, R. T. (2006). Role of nitric oxide in cardiovascular adaptation to intermittent hypoxia. Experimental Biology and Medicine, 231(4), 343-365. https://doi. org/10.1177/153537020623100401

[5] Treuer, A. V., \& Gonzalez, D. R. (2015). Nitric oxide synthases, S-nitrosylation and cardiovascular health: From molecular mechanisms to therapeutic opportunities (review). Molecular Medicine Reports, 11(3), 1555-1565. https://doi.org/10.3892/mmr.2014.2968

[6] Manukhina, E. B., Downey, H. F., Mallet, R. T., Malyshev, I. Yu., \& Vanin, A. F. (2012). Depo oksida azota (NO) i ego adaptivnaya rol' v serdechno-sosudistoi sisteme. [Nitric oxide (NO) stores and their adaptive function in the cardiovascular system]. Patogenez, 10(2), 19-27. [in Russian]

[7] Abe, H., Semba, H., \& Takeda, N. (2017). The Roles of Hypoxia Signaling in the Pathogenesis of Cardiovascular Diseases. Journal of Atherosclerosis and Thrombosis, 24(9), 884-894. https://doi.org/10.5551/jat.RV17009

[8] Kolesnyk, Y. M., Isachenko, M. I., Melnikova, O. V., \& Hrekova, T. A. (2018). Characteristics of the nitric oxide system indicators in the left ventricle myocardium in SHR. Pathologia(3), 278-283. https://doi. org/10.14739/2310-1237.2018.3.151670

[9] Kolesnyk, Y. M., Hancheva, O. V., Abramov, A. V., Ivanenko, T. V., Fedotova, M. I., \& Danukalo, M. V. (2016). Sposib modeliuvannia fiziolohichnoho remodeliuvannia miokarda u dribnykh hryzuniv [Method for modeling physiological myocardial remodeling in small rodents]. Ukraine Patent UA 112290. Retrieved from https://base.uipv.org/ searchlNV/search.php?action=viewdetails\&ldClaim=230277

[10] Pro zakhyst tvaryn vid zhorstokoho povodzhennia. Zakon Ukrainy vid 21.02.2006 no 3447-IV [On the Protection of Animals from Brutal Treatment. Law of Ukraine on February 21, 2006 no 3447-IV] Retrieved from https://zakon.rada.gov.ua/laws/main/3447-IV

[11] Gorbunov, N. V. (1995). Opredelenie stabil'nykh metabolitov oksida azota po Grissu v biologicheskom material [Determination of stable nitric oxide metabolites by Griss in biological material]. Byulleten enksperimental'noi biologii i meditsiny, 120(7), 40-48. [in Russian].

[12] Fedotova, M. I., Kovalov, M. M., Zhulinskyi, V. O., \& Kadzharian, Ye. V. (2017). Osoblyvosti ekspresii izoform syntazy oksydu azotu u miokardi livoho shlunochka shchuriv pry arterialnii hipertenzii riznoho henezu [Peculiarities of expression of nitric oxide synthase isoforms in left ventricular myocardium of rats in arterial hypertension of various geneses]. Aktualni problemy suchasnoi medytsyny, 17(4.2), 91-95. [in Ukrainian].
[13] Zaitsev, V. M., Liflyandskii, V. G., \& Marinkin, V. I. (2006). Prikladnaya meditsinskaya statistika. [Applied Medical Statistics]. St. Petersburg: Foliant [in Russian].

[14] Chis, I. C., Baltaru, D., Dumitrovici, A., Coseriu, A., Radu, B. C., Moldovan, R., \& Muresan, A. (2018). Protective effects of quercetin from oxidative/nitrosative stress under intermittent hypobaric hypoxia exposure in the rat's heart. Physiology International, 105(3), 233-246. https://doi.org/10.1556/2060.105.2018.3.23

[15] Na, H., Chung, H., Ha, K., Lee, H., Kwon, Y., Billiar, T. R., \& Kim, Y. (2008). Chapter 17 detection and measurement for the modification and inactivation of caspase by nitrosative stress in vitro and in vivo. https://doi.org/10.1016/S0076-6879(08)01217-2

[16] Rossier, B. C., Bochud, M., \& Devuyst, O. (2017). The hypertension pandemic: An evolutionary perspective. Physiology, 32(2), 112-125. https://doi.org/10.1152/physiol.00026.2016

[17] Meerson, F. Z., \& Pshennikova, M. G. (1988). Adaptatsiya k stressovym situatsiyam i fizicheskim nagruzkam [Adaptation to stressful situations and physical activity]. Moscow: Izdatelstvo Meditsina. [in Russian].

[18] Zhang, Y. H. (2017). Nitric oxide signalling and neuronal nitric oxide synthase in the heart under stress. F1000Research, $6 \mathrm{https}: / /$ doi. org/10.12688/f1000research.10128.1

[19] Carnicer, R., Suffredini, S., Liu, X., Reilly, S., Simon, J. N., Surdo N. C., ... Casadei, B. (2017). The subcellular localization of neuronal nitric oxide synthase determines the downstream effects of NO on myocardial function. Cardiovascular Research, 113(3), 321-331. https:// doi.org/10.1093/cvr/cvx002

[20] Lefer, D. J. (2006). Induction of HIF-1 $\alpha$ and iNOS with siRNA: A novel mechanism for myocardial protection. Circulation Research, 98(1), 10 11. https://doi.org/10.1161/01.RES.0000200398.52220.cc

[21] Ding, H., Zhu, H., Dong, J., Zhu, W., Yang, W., Yang, H., \& Zhou, Z. (2005). Inducible nitric oxide synthase contributes to intermittent hypoxia against ischemia/reperfusion injury. Acta Pharmacologica Sinica, 26(3), 315-322. https://doi.org/10.1111/j.1745-7254.2005.00046.x

[22] La Padula, P. H., Etchegoyen, M., Czerniczyniec, A., Piotrkowski, B. Arnaiz, S. L., Milei, J., \& Costa, L. E. (2018). Cardioprotection after acute exposure to simulated high altitude in rats. role of nitric oxide. Nitric Oxide - Biology and Chemistry, 73, 52-59. https://doi.org/10.1016/j. niox.2017.12.007

[23] Capettini, L. S. A. Cortes, S. F. \& Lemos, V. S. (2010). Relative contribution of eNOS and nNOS to endothelium-dependent vasodilation in the mouse aorta. European Journal of Pharmacology, 643(2-3) 260-266. https://doi.org/10.1016/i.ejphar.2010.06.066

[24] Forstermann, U., \& Munzel, T. (2006). Endothelial nitric oxide synthase in vascular disease - From marvel to menace. Circulation, 113(13) 1708-1714. https://doi.org/10.1161/circulationaha.105.602532

[25] Macdonald, W. A., \& Hool, L. C. (2008). The effect of acute hypoxia on excitability in the heart and the L-type calcium channel as a therapeutic target. Current Drug Discovery Technologies, 5(4), 302-311. https://doi. org/10.2174/157016308786733546

[26] Wyatt, A. W., Steinert, J. R., \& Mann, G. E. (2004). Modulation of the L-arginine/nitric oxide signalling pathway in vascular endothelial cells https://doi.org/10.1042/bss0710143

[27] Rus, A., del Moral, M., Molina, F., \& Peinado, M. (2011). Does inducible NOS have a protective role against hypoxia / reoxygenation injury in rat heart? Cardiovascular Pathology, 20(1), e17-e25. https://doi. org/10.1016/j.carpath.2010.01.002 